\title{
Sustainopreneurship and Its' Role in Sustainable Fashion Brands of India
}

\author{
Divyansha Kumar, Anubha Vashisht
}

\begin{abstract}
This study focuses on sustainopreneurship (Abrahamsson, 2007; Schlange 2009) and its' role in developing, innovative yet sustainable business practices for the sustainable fashion brands of India. The findings of this study are centring on selected brands which are coming up with sustainable solutions within the context of the processes, product, people and work-place. This study uses in-depth interviews and guided conversations with the entrepreneurs of the selected sustainable fashion brands of India to build case studies on two such brands following the ethnographic methodology (O'Reilly, 2012). The first case focuses on a brand which is moving towards a zerowaste production unit by creating their sustainable solutions of procuring raw materials, designing the products and innovating with the waste generated at their workplace. The second case is about a brand which focuses on up-cycling the already produced material which has been discarded by the manufacturers or producers due to defects, misprints, stitching wastes among others. These two brands use different ways to design their products and have come with sustainable solutions for a greener planet and have been ardently working towards that goal. The study concludes that the zeal behind these brands' practices, visions and goals is because of the moral compass of their respective entrepreneurs pointing towards ethical behaviour which forms the roots of 'sustainopreneurship'.
\end{abstract}

Keywords: Entrepreneurs, Ethical-Behaviour, Sustainability, Sustainopreneurship.

\section{INTRODUCTION}

In this research the authors have tried to explore a new practice which has recently been very popular amongst the new age entrepreneurs, termed as 'sustainopreneurship'. Sustainopreneurship as a concept was first introduced in 2000; the phenomenon developed with publications in 2003, and further evolved and tentatively was defined in 2006 (Abrahamson, 2007). In the simplest of terms it means giving sustainable solutions or answer to any problems in the form of a business model. Hence moving it away from the entrepreneurial cognition theory (Mitchell, R. K et al., 2002) as well as the resource based theory of entrepreneurship (Alvarez, S. A., \& Busenitz, L. W., 2001).

Sustainability as a concept means the overall endurance of our ecosystem and not just the processes related to the operation management. As we know, due to scarce resources and endless human wants, the existing gap has increased, as a result the interest among the consumers all over the world about the sustainable future of the environment and its' resources has been intrigued.

Revised Manuscript Received on September 10, 2019.

Divyansha Kumar, Junior Research Fellow, Faculty of Management, Symbiosis Centre for Management Studies, NOIDA, Symbiosis International (Deemed University), Pune, Maharshtra, India.

(Email: divyansha.kumar@gmail.com)

Dr Anubha Vashisht, Professor and Director, Symbiosis Centre for Management Studies, NOIDA, Symbiosis International (Deemed University), Pune, Maharashtra, India.

(Email: director@scmsnoida.ac.in)
The current awareness about the ecological balances and environmental protection has provided more behavioural outcome towards sustainable product production which has affected the industries as well as the consumers. This growth of ethical culture (Shaw et al., 2006) as a result, has made the brands more ethically conscious and aware of the sustainable resources and the environment surrounding them. Thus ensuring sustainability of not just the process but also the products manufactured the people responsible for it and the work-place.

Today the fashion industry is the second largest polluting industry in the world and Indian textile industry is one of the largest manufacturer and raw material producer in this sector with the mill sector being the second largest in the world according to the Annual Report (2017-18) of Ministry of Textile, Government of India. Since the fabrics are made out of both renewable and non-renewable materials like polyester which takes around 200years to break down therefore there are brands coming up with sustainable solutions to such problems. Most of the ethically conscious brands believe that eco-friendly products are safer to use and their marketing strategies have been influenced more by the factors contributing to the sustainable practices. At present, the primary focus is being given on sustainable solutions such as organic dyes, azo-free dyes, recycled and up-cycling the products, stream-lining the process with minimum waste generation and many others. Therefore, the worldwide misery for sustainable development has emphasized the need for stronger ethical behaviour of the corporates.

Sustainable solutions in fashion industry has led to the appearances of practices like green marketing (Stanton and Futrell, 1987), slow fashion, circular fashion and conscious purchasing all of them speak for the increasing market for sustainable and socially responsible products and services Sustainability contains an extensive series of tasks such as adjustment of product, production process transformation, different advertising style, modifications in packaging, etc., that aims at sustainable development. Although the awareness has increased, still, there are a number of potential challenges and issues that are essential to be conquered by inculcating the ethical behaviour by recognizing the key factors responsible for bridging the gap of ethical/conscious purchasing (Bray et al., 2011).

In this study, the authors will be focusing on the sustainable solutions within the framework of the processes, product, people and work-place and the impact they have on the organizations' objectives, marketing strategies and product life cycle. This should result in the identification of 
the parameters responsible for the concept of sustainopreneurship in ethically conscious entrepreneurs. The analysis will be based on the two case studies of sustainable fashion brands of India who have been successful in coming up with sustainable solutions in the line of slow fashion.

\section{METHODOLOGY}

This study uses in-depth interviews and guided conversations with the entrepreneurs of the selected sustainable fashion brands of India to build case studies on two such brands following the ethnographic methodology (O'Reilly, 2012).

\section{A. Study Universe}

The study universe of this research was limited to sustainable fashion brands which fall under the umbrella of the textile industry, which is the second largest polluting industry in the world. The study universe in terms of geographic segmentation was limited to the Indian textile industry since it is the largest manufacturer and raw material producer of textiles. Also according to the MIT report (2015) India, China and Bangladesh produce a cutting room waste mounting to eighty billion square metres of fabric each year which ends up in land-fills.

\section{B. Sampling}

Since it was an ethnographic study therefore snowball sampling was used to contact the founders of the brands. Currently there about 20 odd brands registered as sustainable fashion brands who have thrived in this industry for more than 2 years. For this study the authors contacted 2 out of these 30 brands for in-depth interviews for better understanding of their ideologies, processes and objectives. The first brand is called 'Dhuri', owned by Madhurima Singh, who is a fashion designer from NIFT Mumbai and has worked with the quintessence of Indian fashion himself, Sabyasachi Mukherjee. The second case is about the brand called 'Doodlage', co-founded by Kriti Tula, who is a trained apparel designer and has won several accolades for her work in up-cycled and ethical fashion.

\section{Objectives}

To study the factors responsible for conscious and ethical behaviour of the entrepreneurs.

To study the parameters of sustainability in fashion industry of India.

\section{RESULTS}

This study has focussed on brands in the fashion industry of India which have come up with sustainable solutions to the never ending problems of land-fills. In this part of the study the authors have analysed the findings of this research by using thematic analysis of the transcripts of the in-depth interviews. Each case has been divided in several themes based on the keywords most frequently used or underlined.

\section{A. Case One: Dhuri}

Dhuri blends Science with Heritage. The brand is a metaphor of classic fabrics, ranging from Handloom to the latest organics like Ingeo (corn fibre), Tencel (Eucalyptus
Fibre), Soya protein fibre, Bamboo fibre and banana fibre. The puts in a lot of details behind each design and details of each of its' apparel keeping a balance of creativity and functionality.

\section{Growing Organically}

Dhuri makes its' own lot of organic dyes instead of buying common chemical dyes as it believes that the closer one is to nature the better chances of sustaining. Apart from dyes, Dhuri also prefers using fabrics made out of plants which are biodegradable and have a less life in land-fills. As a result they use corn fabrics, banana fabrics, milk protein fabrics, soya protein fabrics, eucalyptus fabrics apart from hand loomed fabrics like cotton, jute and silk.

\section{Fair Wages, Fair Trade}

In most of the conversation, what Dhuri strongly believes is providing fair wages to all its' in-house team and fair trade to its' out-bound logistics. They have created an open environment for the in-house team in terms of working hours, equal pay for equal amount of work, no extra work pressure and understanding in terms of medical and personal emergencies. They have also collaborated with an NGO called 'Masterji' which empowers local village women as skilled tailors and embroiderers. Dhuri has been very particular in attaining their raw material from their in-bound logistic traders by ensuring they have proper certifications of organic and sustainable fabrics.

\section{Circular Fashion}

The concept of circular fashion was originated in 2014 by Dr Brismar who relates it to circular economy and sustainable development with the fashion industry. It can be defined as 'clothes, shoes or accessories that are designed, sourced, produced and provided with the intention to be used and circulate responsibly and effectively in society for as long as possible in their most valuable form, and hereafter return safely to the biosphere when no longer of human use. (Dr. Anna Brismar, 2017, circularfashion.com)'. Dhuri strongly upholds this principle and designs its' products keeping in mind the principles of circular fashion.

\section{B. Case Two: Doodlage}

Doodlage as a brand believe in slow-fashion, up-cycling and reducing any kind of waste generated from the textile industries. They make their designer pieces from scraps, cutting room waste, rejected fabrics and other kinds of factory waste. Their mantra for sustainability not just stops at them but in educating their customers as well how to repair and repeat the same product in different ways.

\section{Care and Repair}

Doodlage makes its' consumers aware of the post purchase of the products by educating them of washing, drying, ironing and disposal of the products as $36 \%$ of the total environmental impact of a garment's lifecycle can be resolved by taking care of the products. They have started

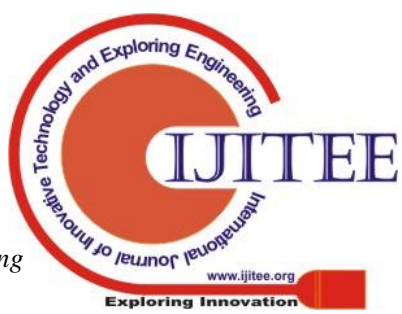


their own revolution called as 're-love-ution' which thrives on the motto 'Care with love, Repair with a purpose'.

\section{Reuse the fabric}

Doodlage procures it fabric from the cutting, stitching waste, defected, mis-printed fabrics of factories around India. By using this fabric they approximately contribute in saving almost $20 \%$ of the total fabric which would have landed in the land-fill daily. Apart from this they also reuse their own waste from productions by converting it into accessories or other home use items. This practice is helping them become a zero-waste production unit.

\section{Slow Fashion}

In today's world because of reducing costs, streamlined operations, and rising needs, the apparel production has doubled in the last two decades. Each year every person on an average has increased his purchase by more than $60 \%$. All this has contributed because of big brands promoting 'fast-fashion', where the idea is to not repeat the clothes hence adding more to the land-fills. To bring a sustainable solution to this problem some brands like Doodlage have started promoting 'slow-fashion' as a trend and promote the idea of repeating the apparel multiple times in different looks and style.

\section{DISCUSSION}

The objective of this study was to study the parameters the parameters responsible for sustainability in fashion industry which are being discussed in this part. The most prominent parameters which made corporate as well as the consumers shift to ethically conscious thinking were the place.

\section{A. People}

According to Global Fashion Agenda and the Boston Consulting Group Report (2017) by 2030 the fashion industry is projected to have 1.6 million injuries by not taking care of their people. Young workers have been killed in factory disasters for more than a century and big brands do not compensate them in any kind. As a result fashion industry is considered as one the most brand-centric industry with profit always coming first rather than sustainable investments. This problem has given rise to a paradigm shift of circular fashion industry from linear fashion industry. The solution to these issues have been discussed in the case studies in this study where they provide care, compensation, equal rights and recognize their work-force resulting to sustainable answers.

\section{B. Process}

The fashion industry for the past century has been polluting the environment with it pre and post waste by adding toxic chemicals in the water bodies, production and consumer waste in the landfills and harmful pollutants in the air. Due to this several movements have originated making the corporates and consumers conscious about their habits. Sustainable solutions like greener supply chains, ecofriendly dyes and fabrics, re-using production waste and more use of organic material have come into practice, which are resolving the problem. The need for the hour is to make people involved, the process, the product and the work-

everyone involved in the process of a product more ethically conscious, starting from procurement of raw material to designing of the product to manufacturing of final products to selling and after use of the products. The sustainable fashion brands like Dhuri and Doodlage have come us with innovative sustainable solutions which are helping in this direction

\section{Product}

One of the most widely used fabrics in apparel is cotton which takes up to 700 gallons of water to produce just enough fabric one shirt. This about of water is enough to for a person to survive for more than two decades. The solution to this problem is to shift to ore organic fibres such as soya protein or milk protein fibres, banana fabrics, corn fabrics which use much less natural resources and are more ecofriendly.

\section{Work-place}

The number of people working in the fashion industry is 75 million out of which more than $80 \%$ are women garment workers. The increasing demand of fast fashion has led to irresponsible work-place practices such as slavery, child labour, unfair trade, unhealthy living conditions, unequal pay for gender. The need for the hour is to eradicate the root cause of this problem by following slow fashion, educating consumers and corporates. Social media movements such as '\#whomademyclothes' have resulted in big names like HnM, Adidas, come up with conscious line of clothing where they have answered the questions of ethically conscious buyers.

\section{CONCLUSION AND IMPLICATIONS}

For big conglomerates, pivoting niche segmentation, changing supply chains, and working with new or old manufacturers, and demanding higher standards, can be stimulating. The strongest driver for any business to move toward sustainability is a genuine commitment from the very top of the organization. This has been proven in this study as both the brands, Dhuri and Doodlage have highly committed, environmentally responsible and ethically conscious entrepreneurs. It is the values of both the entrepreneurs of the respective brands which have laid the foundations of their business model and have been able to attain label the sustainable fashion brands of India. Brands like these have been able to come with revolutions like green supply chain, equal pay, happy in-house work force, greener products, conscious consumers and zero waste production units all of which are the answer to our dying planet.

\section{REFERENCES}

1. Abrahamsson, A. (2007, June). Researching Sustainopreneurship-conditions, concepts, approaches, arenas and questions. In Proceedings of the International Sustainable Development Research Conference.

2. Alvarez, S. A., \& Busenitz, L. W. (2001). The entrepreneurship of resource-based theory. Journal of 
management, 27(6), 755-775.

3. Bray, J., Johns, N., \& Kilburn, D. (2011). An Exploratory Study into the Factors Impending Ethical Consumption. Journal of Business Ethics, 98(4), 597-608.

4. Mitchell, R. K., Busenitz, L., Lant, T., McDougall, P. P., Morse, E. A., \& Smith, J. B. (2002). Toward a theory of entrepreneurial cognition: Rethinking the people side of entrepreneurship research. Entrepreneurship theory and practice, 27(2), 93-104.

5. O'Reilly, K. (2012). Ethnographic Methods. London: Routledge.

6. Schlange, L. E. (2009). Stakeholder Identification in Sustainability Entrepreneurship. Greener Management International, (55).

7. Stanton, W.J. and Futrell, C. (1987), Fundamentals of Marketing, McGraw-Hill, New York, NY.

\section{AUTHORS PROFILE}

Miss Divyansha Kumar is a PhD Research Fellow at Symbiosis International (Deemed University) under the guidance of Dr Anubha Vashisht. Her research areas are sustainable marketing, consumer ethical behaviour and corporate ethical behaviour. She holds a B.Tech degree in Electronics and Instrumentation Engineering and a PGDM in Marketing and Operations. She has a combined work experience of almost 5 years as a software engineering in business intelligence tools, life skill facilitator and an academic researcher. She has presented her research papers at several International Conferences out of which some research papers have been published in UGC recognised journals. She has received many accolades for her case presentations skills, and academic performances.

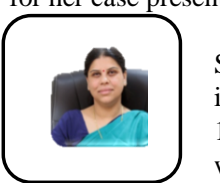

Prof. (Dr.) Anubha Vashisht is the Director of Symbiosis Centre for Management Studies NOIDA. She is a Marketing Professional with a varied experience of 19 years in academics, industry and research. After working with many leading FMCG players she moved to academia to share her experience with the young learners. She has conducted MDPs/Workshops and has been associated extensively with Research \& Consultancy assignments for reputed corporates. She also handled International Consultancy assignments at Telxess Consulting Services (P) Ltd.

She is a recognized guide and external expert for the doctoral programs at various renowned universities. She is also a motivational speaker and has conducted workshops on topics like Creative Decision Making, Habits of Successful people, Business Plan, Self-Management. She is the member of Board of Studies at the University Level. Besides this she is on editorial board of many International Journals. 